BIOMEDICINE

\title{
Overexpression of genes at different stages of astrosutic glioma development
}

\author{
V. V. Dmytrenko, O. I. Boyko, C. O. Shostak, O. E. Symyrenko, T. V. Bukreyeva, \\ V. D. Rozumenko', T. A. Malysheva', M. I. Shamaev', Y. P. Zozulya', V. M. Kavsan \\ The Institute of Molecular Biology and Genetics \\ 150 Zabolotny Str., Kyiv, 03143, Ukraine \\ ${ }^{1}$ The Institute of Neurosurgery named after Romodanov A.P., Academician \\ of Medical Sciences of Ukraine \\ 32 Manuylsky Str., Kyiv \\ E. mail: dmitrenko@imbg.org.ua
}

\begin{abstract}
Public database of Serial Analysis of Gene Expression (SAGE) was used for identification of potential human astrocytic glioma molecular markers. The comparison of nine glioblastoma SAGE-libraries, eleven anaplastic astrocytoma SAGE-libraries, eight diffusive astrocytoma SAGE-libraries, and five normal human brain SAGE-libraries revealed 57 genes with more than 5-fold increase of expression in astrocytic gliomas ( $P \# 0.05)$ comparing to the normal human brain. Besides the genes expression changes which occur at the early stage of astrocytomas formations and are revealed also during the subsequent stages of progression, some changes are characteristic only of highly malignant stages of tumor development while they are absent in the tumors of low stage of malignancy. The analysis of revealed genes expression can be used for glial tumor molecular classification, diagnosis, prognostic evaluation and determination of potential targets for anticancer therapy.
\end{abstract}

Key words: SAGE, differential expression, astrocytic glioma, molecular markers.

Introduction. Malignant gliomas, the most widely spread primary tumors of a human brain, are characterized by their considerable aggressivity, high invasion, and neurological destruction. The majority of gliomas (up to the half of all intracranial tumors) is comprised of astrocytic gliomas, human brain macroglia neoplasms. The tumors

(C) V. V. DMYTRENKO, O. I. BOYKO, C. O. SHOSTAK, O. E. SYMYRENKO, T. V. BUKREYEVA, V. D. ROZUMENKO, T. A. MALYSHEVA, M. I. SHAMAEV, Y. P.ZOZULYA', V. M. KAVSAN, 2006 progress through the stages of increasing malignancy, associated with genetic anomalies accumulation on different chromosomes and gene expression changes. WHO [1] classification is based on certain histological tumor cell properties and histological diagnosis is a basic criterion for prognostic evaluation and therapy. The efforts directed towards establishing correlation between a genotype and a phenotype of glial tumors did not come to univalent results. For example, gene p53 mutations (a distinguishing feature of diffusive astrocytomas, chemotherapy stable) and the loss of heterozygosity ( $\mathrm{LOH}$ ) on $1 \mathrm{p}$ and $19 q$ chromosomes (distinguishing features of oligodendrogliomas, 
which are associated with their sensitivity to chemotherapy and better prognosis) were discovered in astrocytomas, as well as in oligodendrogliomas [2]. The conclusion of another work based on astrocytomas and oligodendrogliomas genetic analysis was that genetic changes (p53 gene mutation and LOH on 1p and 19q chromosomes) cannot be accepted as trustworthy prognostic factors.

With the advent of cDNA-microarrays, oligonucleotide chips, Digital Differential Display (DDD), and Serial Analysis of Gene Expression (SAGE) it became possible to identify genes, whose expression is changing at various diseases. These technologies allow identifying not only single genes but gene clusters that characterize gene expression profiles in norm as well as in disease. The differences in gene expression levels may be used not only for tumor classification and prognosis of medical treatment response but also for multiple markers identification for early cancer diagnostics [4].

Therefore, molecular astrocytoma and oligodendroglioma subtypes of the $2^{\text {nd }}-4^{\text {th }}$ malignancy degrees, possessing similar LOH $1 \mathrm{p}$ and $19 \mathrm{q}$ status, but different in gene expression profiles which correlate with certain clinical features of these tumors, were identified in works on glioma gene expression profiling with differential hybridization cDNA-microarrays[5] and oligonucleotide microarrays[6].

It was also established that the expression of a relatively small quantity of genes was different in malignant and normal tissues. The differences in these genes expression can reflect the important changes in such critical processes as cell proliferation, proteasomal function, energy metabolism and signal transduction. However, considerable heterogeneity of glial tumors and a great number of ways of their development demand further investigation. We have analyzed gene expression in astrocytic gliomas of the $2^{\text {nd }}-4^{\text {th }}$ malignancy degrees and normal human brain using SAGE to identify genes that may be used as glial tumors molecular markers. The following results demonstrate that approximately 60 genes are expressed on a significantly higher level in astrocytic gliomas in comparison with normal human brain. Discovered genes are potential markers for glial tumors molecular classification, diagnosis, prognostic evaluation and antitumor therapy.

Materials and Methods. Nine glioblastoma SAGE-libraries (GB, astrocytomas of the $4^{\text {th }}$ degree by WHO classification), eleven anaplastic astrocytoma SAGE-libraries (AA, astrocytomas of the $3^{\text {rd }}$ degree), eight diffusive astrocytoma SAGE-libraries (A, astrocytomas of the $2^{\text {nd }}$ degree), and five normal human brain SAGE-libraries (NHB) were analyzed to compare gene expression using the DGED search program (Digital Gene Expression
Displayer) and the SAGE Genie database (http://cgap.nci.nih.gov/SAGE). Taking into consideration the samples combination in some SAGE-libraries (GSM765 is a pool of 5 glioblastomas, and GSM763 is a pool of 2 samples of normal human brain), actually the analysis of $13 \mathrm{~GB}$ and 6 NHB samples was carried out (Table 1). The Unigene NCBI database (http://www.ncbi.nlm.nih.gov) was used to search for cDNA clones, which contain coding parts of discovered mRNA. The selected cDNA clones were obtained from the RZPD, Resource Center/Primary Database of the Genome of a Human project, Germany (http://www.rzpd.de).

The surgical samples of glial astrocytomas and normal human brain (histologically normal human brain tissue adjacent to a tumor which is forcedly extracted together with the tumor during the operation) were obtained from the Institute of Neurosurgery named after Romodanov A.P., Academician of Medical Sciences of Ukraine, Kyiv. 35 tumor samples, including 14 glioblastomas, 10 anaplastic astrocytomas, 6 astrocytomas, 2 oligoastrocytomas, 1 anaplastic oligodendroglioma, were analyzed in all.

Total RNA was extracted from tissues, frozen in liquid nitrogen, using the method of phenol extraction from guanidineisothiocyanate solution, as it was described in the previous works $[7,8]$. RNA (10mkg for a lane) was fractionated in horizontal $1.5 \%$ agarous gel in the presence of 2.2M of formaldehyde in borate buffer ( $0.2 \mathrm{mM}$ EDTA, $\mathrm{pH}$ $8.0 ; 30 \mathrm{mM}$ boric acid; $3.3 \mathrm{mM}$ natrium tetraborate, $\mathrm{pH}$ 7.5), then it was transferred to nylon membranes Hybond-N (Amersham Pharmacia Biotech, Austria).

RNA was hybridized for 16 hours at the temperature of $42^{\circ} \mathrm{C}$ with ${ }^{32} \mathrm{R}$-marked cDNA samples in the solution of $50 \%$ formamide, 5xSSC, 5xDenhardt, $0.1 \%$ SDS, $100 \mathrm{Mg} / \mathrm{ml}$ of salmon DNA. The filters were washed 2 times 15 minutes each at the room temperature in the solution of $2 \mathrm{xSSC}, 0.1 \%$ SDS; one time for 15 minutes in the solution of $2 \mathrm{xSSC}, 0.1 \% \mathrm{SDS}$ at the temperature of $65^{\circ} \mathrm{C}$; finally in the solution of $0.2 \mathrm{xSSC}, 0.1 \% \mathrm{SDS}$ for 15 minutes at the temperature of $65^{\circ} \mathrm{C}$. The exposure of membranes on the $\mathrm{X}$-ray film was conducted with the usage of the intensifying screen at the temperature of $-70^{\circ} \mathrm{C}$. The membranes were washed and hybridized repeatedly with the ${ }^{32} \mathrm{R}$-labelled cDNA of the human B-actin as the control of loading RNA on the agarous gel. Densimetry of hybridizational signals was carried out using the Scion Image 1.62c program.

Results and Discussion. To determine relative levels of genes expression in astrocytic tumors of different malignancy degrees and in NHB with the help of SAGE, we used the public database of CGAP (Cancer Genome Anatomy 
Table 1 .

SAGE-libraries of astrocytic gliomas analyzed in this work.

\begin{tabular}{c|c|}
\hline Library name & \\
\hline
\end{tabular}

Quantity of "tags" in the library

\section{Normal Human Brain}

Normal human thalamus SAGE library (GSM713: SAGE_Brain_normal_thalamus_B_1)

Normal human brain SAGE library (GSM676: SAGE_Brain_normal_cortex_B_BB542)

Normal human brain SAGE library (GSM763: SAGE_Brain_normal_cortex_B_pool6)

Normal human cerebellum SAGE library (GSM695: SAGE_Brain_normal_cerebellum_B_BB542)

Normal human cerebellum SAGE library (GSM761: SAGE_Brain_normal_cerebellum_B_1)

Total quantity of "tags" in the pool of SAGE-libraries of NHB

24015

94233

62451

40500

50385

271584

\section{Diffusive astrocytomas}

Astrocytoma grade II SAGE library (GSM1732: SAGE_Brain_astrocytoma_grade_II_B_H127) Astrocytoma grade II SAGE library (GSM14739: SAGE_Brain_astrocytoma_grade_II_B_H563) Astrocytoma grade II SAGE library (GSM14765: SAGE_Brain_astrocytoma_grade_II_B_H530) Astrocytoma grade II SAGE library (GSM2451: SAGE_Brain_astrocytoma_grade_II_B_H388) Astrocytoma grade II SAGE library (SAGE_Brain_astrocytoma_grade_II_B_H359) Astrocytoma grade II SAGE library (GSM14737: SAGE_Brain_astrocytoma_grade_II_B_H518) Astrocytoma grade II SAGE library (SAGE_Brain_astrocytoma_grade_II_B_H516) Astrocytoma grade II SAGE library (SAGE_Brain_astrocytoma_grade_II_B_H501) Total quantity of "tags" in the pool of SAGE-libraries of diffusive astrocytomas

\section{Glioblastomas}

Glioblastoma SAGE library (GSM696: SAGE_Brain_glioblastoma_B_H1110)

Glioblastoma SAGE library (GSM765: SAGE_Brain_glioblastoma_B_pooled)

Glioblastoma SAGE library (GSM14768: SAGE_Brain_glioblastoma_B_R336)

Glioblastoma SAGE library (GSM14769: SAGE_Brain_glioblastoma_B_R70)

Glioblastoma SAGE library (GSM14767: SAGE_Brain_glioblastoma_B_H833)

Glioblastoma SAGE library (SAGE_Brain_glioblastoma_B_H1353)

Glioblastoma SAGE library (SAGE_Brain_glioblastoma_B_H1425C)

Glioblastoma SAGE library (SAGE_Brain_glioblastoma_B_H1371)

Glioblastoma SAGE library (SAGE_Brain_glioblastoma_B_R20)(“tags")

Total quantity of "tags" in the pool of SAGE-libraries of glioblastomas

68986

56428

102322

99099

100600

124805

88990

49338

101053

791621 
Table 2

The list of genes with the more than 5-fold distribution of "tags" in SAGE-libraries of glioblastomas (pool A) and NHB (pool B) according to DGED results.

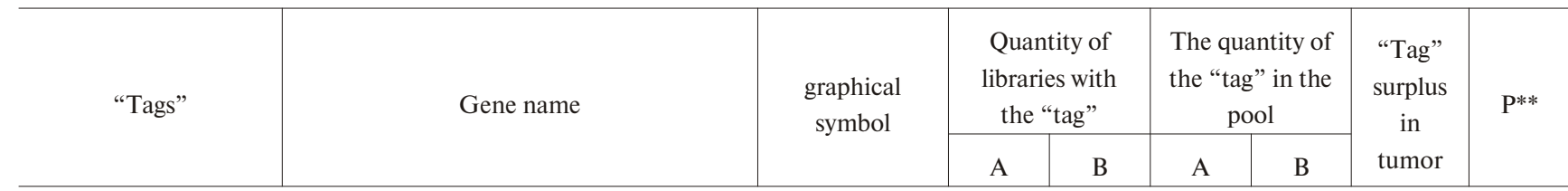

TGGGATTCCC chitinase 3-like 2

CCACAGGGGA collagen, type III, alpha 1

(Ehlers-Danlos syndrome type IV, autosomal dominant)

AGTGGTGGCT

TTAAATAGCA

fibromodulin

stress-associated endoplasmic reticulum protein 1

GTCAACAGTA ATP-binding cassette, sub-family $\mathrm{C}$ (CFTR/MRP), member 3

TGCTCCTACC Fc fragment of IgG binding protein FCGBP

GTATGGGCCC

ACCAAAAACC ACATTCTTTT

AGTACCTTAT

GACCACCTTT ATCCTGAGTT

GAAATAAAGC

TTTGGTTTTC ATAATAAAGC

CATATCATTA

TCACCAAAAA GCCCTTTCTC GCCAACAACG CTTGGGTTTT

GCTGCCCTTG ATCTTGTTAC AGAAAGATGT TAACTCTCCT

AGAACCTTCC chitinase 3-like 1 (cartilage glycoprotein-39) collagen, type I, alpha 1 glycoprotein (transmembrane) nmb epidermal growth factor receptor (erythroblastic leukemia viral (v-erb-b) oncogene homolog, avian)

microfibrillar-associated protein 2 MFAP2

major histocompatibility complex, class II, DQ beta 1

immunoglobulin heavy constant gamma 1 (G1m marker)

collagen, type I, alpha 2

retinoic acid receptor responder (tazarotene induced) 2

insulin-like growth factor binding protein 7

stabilin 1

HLA-DQB 1

IGHG1

COL1A2

RARRES2

IGFBP7

STAB1

mannose receptor, $\mathrm{C}$ type 2

MRC2

nicotinamide $\mathrm{N}$-methyltransferase

insulin-like growth factor 2

NNMT

IGF2

(somatomedin A)

tubulin alpha 6

TUBA6

fibronectin 1

FN1

annexin $\mathrm{A} 1$

scavenger receptor class A,

ANXA1

member 3

SCARA3

major histocompatibility complex, HLA-A

class I, A
CHI3L1

COL1A1

GPNMB

EGFR

$\begin{array}{lllllll}\text { CHI3L2 } & 9 & 0 & 256 & 0 & \mathrm{NaN}^{*} & 0.00 \\ \text { COL3A1 } & 8 & 0 & 169 & 0 & \mathrm{NaN}^{*} & 0.00\end{array}$

$\begin{array}{llllll}9 & 0 & 145 & 0 & \mathrm{NaN}^{*} & 0.01\end{array}$

$\begin{array}{llllll}6 & 0 & 140 & 0 & \mathrm{NaN}^{*} & 0.01\end{array}$

$\begin{array}{llllll}8 & 0 & 103 & 0 & \mathrm{NaN}^{*} & 0.04\end{array}$

$\begin{array}{llllll}9 & 2 & 556 & 2 & 95.44 & 0.00\end{array}$

$\begin{array}{llllll}9 & 2 & 826 & 4 & 70.92 & 0.00\end{array}$

$\begin{array}{llllll}8 & 2 & 1125 & 6 & 64.42 & 0.01\end{array}$

$\begin{array}{llllll}9 & 1 & 361 & 2 & 61.95 & 0.00\end{array}$

$\begin{array}{llllll}8 & 1 & 163 & 1 & 55.93 & 0.01\end{array}$

$\begin{array}{llll}8 & 1 & -163-1 & 55.93-0.01\end{array}$




\begin{tabular}{|c|c|c|c|c|c|c|c|c|}
\hline \multirow[t]{2}{*}{ "Tags" } & \multirow[t]{2}{*}{ Gene name } & \multirow[t]{2}{*}{$\begin{array}{c}\text { graphical } \\
\text { symbol }\end{array}$} & \multicolumn{2}{|c|}{$\begin{array}{l}\text { Quantity of } \\
\text { libraries with } \\
\text { the "tag" }\end{array}$} & \multicolumn{2}{|c|}{$\begin{array}{l}\text { The quantity of } \\
\text { the "tag" in the } \\
\text { pool }\end{array}$} & \multirow{2}{*}{$\begin{array}{l}\text { "Tag" } \\
\text { surplus } \\
\text { in } \\
\text { tumor }\end{array}$} & \multirow[t]{2}{*}{$\mathrm{P}^{* *}$} \\
\hline & & & A & B & A & B & & \\
\hline GCAACAGCAA & Sec61 gamma subunit & SEC61G & 9 & 5 & 576 & 12 & 16.48 & 0.00 \\
\hline ATCAAGAATC & $\begin{array}{l}\text { interferon, gamma-inducible pro- } \\
\text { tein } 30\end{array}$ & IFI30 & 9 & 2 & 185 & 4 & 15.87 & 0.04 \\
\hline GGATATGTGG & early growth response 1 & EGR1 & 9 & 3 & 275 & 6 & 15.73 & 0.01 \\
\hline AATAGAAATT & $\begin{array}{l}\text { secreted phosphoprotein } 1 \\
\text { (osteopontin, bone sialoprotein I, } \\
\text { early T-lymphocyte activation 1) }\end{array}$ & SPP1 & 8 & 4 & 438 & 11 & 13.67 & 0.00 \\
\hline GACTCTTCAG & $\begin{array}{l}\text { serine (or cysteine) proteinase in- } \\
\text { hibitor, clade A (alpha-1 } \\
\text { antiproteinase, antitrypsin), mem- } \\
\text { ber } 3\end{array}$ & SERPINA3 & 9 & 5 & 1239 & 32 & 13.30 & 0.00 \\
\hline GGGCATCTCT & $\begin{array}{l}\text { major histocompatibility complex, } \\
\text { class II, DR alpha }\end{array}$ & HLA-DRA & 9 & 5 & 814 & 22 & 12.71 & 0.00 \\
\hline AGCAGATCAG & $\begin{array}{l}\text { S100 calcium binding protein A10 } \\
\text { (annexin II ligand, calpactin I, } \\
\text { light polypeptide ( } 11) \text { ) }\end{array}$ & S100A10 & 9 & 4 & 475 & 13 & 12.54 & 0.00 \\
\hline TTCACTGTGA & $\begin{array}{l}\text { lectin, galactoside-binding, soluble, } \\
3 \text { (galectin 3) }\end{array}$ & LGALS3 & 9 & 5 & 386 & 11 & 12.04 & 0.00 \\
\hline TTCTATTTCA & moesin & MSN & 9 & 5 & 254 & 8 & 10.90 & 0.05 \\
\hline TGCTGACTCC & nestin & NES & 9 & 4 & 284 & 9 & 10.83 & 0.03 \\
\hline GTTCACATTA & $\begin{array}{l}\text { CD74 antigen (invariant } \\
\text { polypeptide of major } \\
\text { histocompatibility complex, class } \\
\text { II antigen-associated) }\end{array}$ & CD74 & 9 & 5 & 2959 & 99 & 10.29 & 0.00 \\
\hline GTTGTGGTTA & beta-2-microglobulin & $\mathrm{B} 2 \mathrm{M}$ & 9 & 5 & 2830 & 95 & 10.25 & 0.00 \\
\hline СТСТAAGAAG & $\begin{array}{l}\text { complement component } 1, \mathrm{q} \\
\text { subcomponent, alpha polypeptide }\end{array}$ & C1QA & 9 & 5 & 882 & 30 & 10.10 & 0.00 \\
\hline TTTGCACCTT & connective tissue growth factor & CTGF & 9 & 3 & 435 & 15 & 9.95 & 0.01 \\
\hline GGATGTGAAA & CD99 antigen & CD99 & 9 & 5 & 399 & 14 & 9.78 & 0.02 \\
\hline TAATTTTAAC & $\begin{array}{l}\text { protein tyrosine phosphatase, re- } \\
\text { ceptor-type, } Z \text { polypeptide } 1\end{array}$ & PTPRZ1 & 9 & 5 & 336 & 12 & 9.61 & 0.04 \\
\hline TGGCCCCAGG & apolipoprotein C-I & APOC1 & 9 & 3 & 755 & 27 & 9.60 & 0.00 \\
\hline ATGTGAAGAG & $\begin{array}{l}\text { secreted protein, acidic, } \\
\text { cysteine-rich (osteonectin) }\end{array}$ & SPARC & 9 & 5 & 2717 & 112 & 8.35 & 0.00 \\
\hline ACAAAGCATT & $\begin{array}{l}\text { insulin-like growth factor binding } \\
\text { protein } 5\end{array}$ & IGFBP5 & 9 & 5 & 750 & 36 & 7.15 & 0.04 \\
\hline
\end{tabular}

* NaN - "not a number", i.e. absence of gene "tags" in the pool and impossibility of dividing by 0 ; $* * \mathrm{P}-$ possibility

Project). For the previous work the comparison of five SAGE-libraries of GB with two SAGE-libraries of NHB present in this database at that time revealed 117 genes with more than 5-fold expression difference $(\mathrm{P} \# 0.05)$ in $\mathrm{GB}$ comparing to NHB.
Four new SAGE-libraries of GB have recently appeared in SAGE Genie database. Besides, the quantity of SAGE-libraries of anaplastic astrocytomas has increased, they are eleven at present, and there are eight SAGE-libraries of diffusive astrocytomas. The comparison of nine 
Table 3.

Changes of genes expression at different stages of astrocytic gliomas of human

\begin{tabular}{|c|c|c|c|c|c|c|c|c|c|c|c|c|}
\hline \multirow[t]{2}{*}{ "Tag" } & \multirow[t]{2}{*}{$\begin{array}{c}\text { Gene symbolic } \\
\text { notation }\end{array}$} & \multicolumn{4}{|c|}{$\begin{array}{l}\text { The quantity of libraries where } \\
\text { "tag" is present }\end{array}$} & \multicolumn{4}{|c|}{$\begin{array}{l}\text { "Tag" quantity in the united pool } \\
\text { of "tag" libraries, normalized to } \\
\text { 1mln of "tags" }\end{array}$} & \multicolumn{3}{|c|}{$\begin{array}{c}\text { "Tag" surplus in tumour, } \\
\text { in comparison with } \\
\text { NHB }\end{array}$} \\
\hline & & NHB & $\mathrm{A}$ & $\mathrm{AA}$ & GB & NHB & A & AA & GB & A & AA & GB \\
\hline TGGCCCCAGG & APOC1 & 3 & 8 & 11 & 9 & 99 & 836 & 905 & 951 & 9.05 & 9.12 & 9.60 \\
\hline GTTGTGGTTA & $\mathrm{B} 2 \mathrm{M}$ & 5 & 8 & 11 & 9 & 350 & 2737 & 2816 & 3566 & 8.43 & 8.08 & 10.25 \\
\hline GGGCATCTCT & HLA-DRA & 5 & 8 & 11 & 9 & 81 & 605 & 874 & 1026 & 8.02 & 10.81 & 12.71 \\
\hline CATATCATTA & IGFBP7 & 5 & 8 & 11 & 9 & 48 & 1176 & 1154 & 1498 & 26.42 & 24.16 & 31.42 \\
\hline ATGTGAAGAG & SPARC & 5 & 8 & 11 & 9 & 412 & 3852 & 2815 & 3423 & 10.07 & 6.85 & 8.35 \\
\hline TAACТСТССТ & SCARA3 & 3 & 8 & 11 & 9 & 15 & 72 & 108 & 326 & 10.38 & 6.97 & 20.68 \\
\hline GTTCACATTA & CD74 & 5 & 8 & 11 & 9 & 364 & 1630 & 2015 & 3727 & 4.81 & 5.54 & 10.29 \\
\hline TAATTTTAAC & PTPRZ1 & 5 & 8 & 11 & 9 & 44 & 292 & 312 & 423 & 7.10 & 7.08 & 9.61 \\
\hline GACTCTTCAG & SERPINA3 & 5 & 7 & 11 & 9 & 118 & 485 & 758 & 1561 & 4.44 & 6.44 & 13.30 \\
\hline AGCAGATCAG & S100A10 & 4 & 8 & 11 & 9 & 48 & 171 & 264 & 599 & 3.84 & 5.52 & 12.54 \\
\hline CTCTAAGAAG & C1QA & 5 & 8 & 11 & 9 & 110 & 253 & 504 & 1111 & 2.46 & 4.57 & 10.10 \\
\hline GGATGTGAAA & CD99 & 5 & 8 & 11 & 9 & 52 & 275 & 380 & 503 & 5.73 & 7.39 & 9.78 \\
\hline TTCACTGTGA & LGALS3 & 5 & 8 & 10 & 9 & 40 & 74 & 175 & 486 & 1.96 & 4.32 & 12.04 \\
\hline AGAAAGATGT & ANXA1 & 5 & 7 & 10 & 9 & 26 & 194 & 256 & 550 & 8.07 & 9.93 & 21.43 \\
\hline TGGGATTCCC & CHI3L2 & 0 & 5 & 9 & 9 & 0 & 107 & 133 & 323 & $\mathrm{NaN}^{*}$ & $\mathrm{NaN}^{*}$ & $\mathrm{NaN}^{*}$ \\
\hline GCTGCCCTTG & TUBA6 & 3 & 8 & 11 & 9 & 15 & 72 & 108 & 326 & 5.23 & 7.34 & 22.22 \\
\hline TGCTCCTACC & FCGBP & 2 & 8 & 11 & 9 & 7 & 49 & 106 & 700 & 7.18 & 14.44 & 95.44 \\
\hline ATCTTGTTAC & FN1 & 3 & 6 & 10 & 9 & 11 & 30 & 116 & 242 & 2.91 & 10.52 & 21.96 \\
\hline AGAACCTTCC & HLA-A & 5 & 8 & 11 & 9 & 29 & 224 & 185 & 498 & 8.16 & 6.30 & 16.95 \\
\hline TTTGCACCTT & CTGF & 3 & 8 & 11 & 9 & 55 & 229 & 241 & 548 & 4.45 & 4.37 & 9.95 \\
\hline AATAGAAATT & SPP1 & 4 & 8 & 11 & 8 & 40 & 211 & 644 & 552 & 5.59 & 15.94 & 13.67 \\
\hline GTATGGGCCC & CHI3L1 & 2 & 2 & 6 & 9 & 15 & 18 & 280 & 1040 & 1.33 & 19.03 & 70.92 \\
\hline TCACCAAAAA & STAB1 & 1 & 7 & 11 & 8 & 7 & 46 & 51 & 219 & 6.71 & 6.97 & 29.85 \\
\hline GCCСТTTCTC & MRC2 & 1 & 7 & 9 & 9 & 7 & 44 & 40 & 200 & 6.40 & 5.38 & 27.28 \\
\hline CCACAGGGGA & COL3A1 & 0 & 2 & 3 & 8 & 0 & 3 & 5 & 213 & $\mathrm{NaN}^{*}$ & $\mathrm{NaN}^{*}$ & $\mathrm{NaN}^{*}$ \\
\hline AGTGGTGGCT & FMOD & 0 & 5 & 5 & 9 & 0 & 9 & 16 & 183 & $\mathrm{NaN}^{*}$ & $\mathrm{NaN}^{*}$ & $\mathrm{NaN}^{*}$ \\
\hline GTCAACAGTA & $\mathrm{ABCC} 3$ & 0 & 3 & 7 & 8 & 0 & 4 & 14 & 130 & $\mathrm{NaN}^{*}$ & $\mathrm{NaN}^{*}$ & $\mathrm{NaN}^{*}$ \\
\hline ATCCTGAGTT & HLA-DQB1 & 1 & 7 & 11 & 9 & 4 & 46 & 77 & 158 & 13.42 & 21.05 & 42.89 \\
\hline AGTACCTTAT & EGFR & 1 & 7 & 10 & 8 & 4 & 44 & 68 & 205 & 12.80 & 18.35 & 55.93 \\
\hline TTAAATAGCA & SERP1 & 0 & 1 & 1 & 6 & 0 & 1 & 1 & 176 & $\mathrm{NaN}^{*}$ & $\mathrm{NaN}^{*}$ & $\mathrm{NaN}^{*}$ \\
\hline ACCAAAAACC & COL1A1 & 2 & 4 & 2 & 8 & 22 & 4 & 12 & 1418 & 0.21 & 0.53 & 64.42 \\
\hline GACCACCTTT & MFAP2 & 1 & 2 & 5 & 6 & 4 & 2 & 9 & 193 & 0.62 & 2.45 & 52.50 \\
\hline GAAATAAAGC & IGHG1 & 3 & 4 & 6 & 7 & 18 & 26 & 13 & 762 & 1.50 & 0.69 & 41.54 \\
\hline TTTGGTTTTC & COL1A2 & 2 & 2 & 5 & 8 & 18 & 4 & 11 & 667 & 0.25 & 0.59 & 36.32 \\
\hline GCCAACAACG & NNMT & 2 & 3 & 6 & 9 & 7 & 10 & 23 & 193 & 0.94 & 3.06 & 26.25 \\
\hline CTTGGGTTTT & IGF2 & 3 & 5 & 3 & 9 & 15 & 74 & 15 & 364 & 5.38 & 1.04 & 24.80 \\
\hline GCAACAGCAA & SEC61G & 5 & 8 & 11 & 9 & 44 & 51 & 861 & 726 & 1.25 & 19.53 & 16.48 \\
\hline ATCAAGAATC & IFI30 & 2 & 5 & 9 & 9 & 15 & 142 & 103 & 304 & 1.56 & 4.04 & 15.87 \\
\hline TTCTATTTCA & MSN & 5 & 8 & 10 & 9 & 29 & 128 & 82 & 320 & 4.68 & 2.78 & 10.90 \\
\hline ACATTCTTTT & GPNMB & 1 & 5 & 11 & 9 & 7 & 452 & 63 & 455 & 65.90 & 7.22 & 61.95 \\
\hline
\end{tabular}




\begin{tabular}{|c|c|c|c|c|c|c|c|c|c|c|c|c|}
\hline \multirow[t]{2}{*}{ "Tag" } & \multirow[t]{2}{*}{$\begin{array}{l}\text { Gene symbolic } \\
\text { notation }\end{array}$} & \multicolumn{4}{|c|}{$\begin{array}{l}\text { The quantity of libraries where } \\
\text { "tag" is present }\end{array}$} & \multicolumn{4}{|c|}{$\begin{array}{l}\text { "Tag" quantity in the united pool } \\
\text { of "tag" libraries, normalized to } \\
1 \mathrm{mln} \text { of "tags" }\end{array}$} & \multicolumn{3}{|c|}{$\begin{array}{c}\text { "Tag" surplus in tumour, } \\
\text { in comparison with } \\
\text { NHB }\end{array}$} \\
\hline & & NHB & $\mathrm{A}$ & AA & GB & NHB & A & AA & GB & A & AA & GB \\
\hline ATAATAAAGC & RARRES2 & 1 & 8 & 7 & 9 & 7 & 117 & 71 & 258 & 17.02 & 9.67 & 35.17 \\
\hline TGCTGACTCC & NES & 4 & 8 & 11 & 9 & 33 & 142 & 116 & 358 & 4.61 & 3.51 & 10.83 \\
\hline ACAAAGCATT & IGFBP5 & 5 & 8 & 11 & 9 & 132 & 311 & 270 & 945 & 2.52 & 2.04 & 7.15 \\
\hline GGATATGTGG & EGR1 & 3 & 8 & 11 & 9 & 22 & 351 & 177 & 347 & 17.07 & 8.04 & 15.73 \\
\hline
\end{tabular}

*NaN - "not a number", i.e. absence of gene "tags" in the pool and impossibility of dividing by 0 ;

**P - possibility
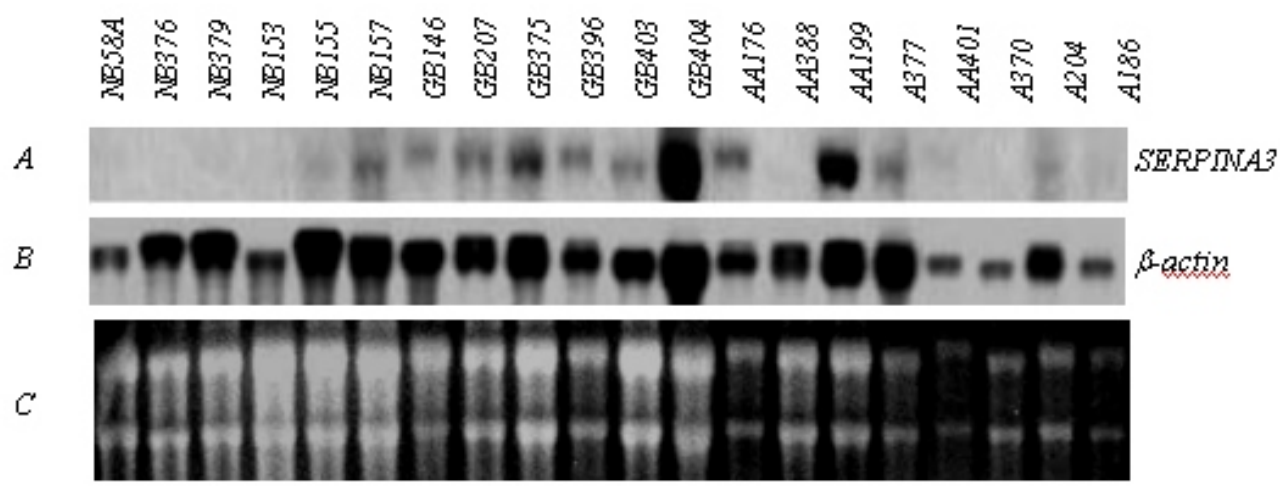

D

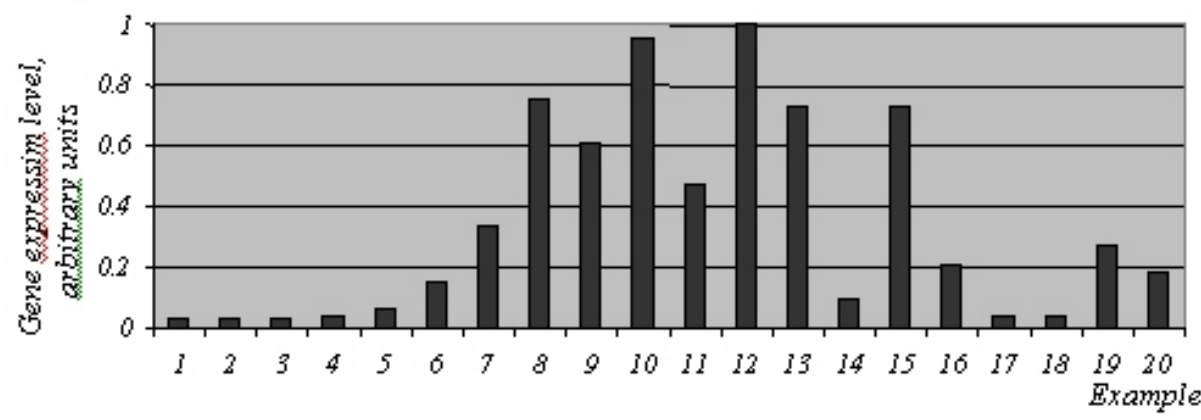

Fig 1. Genes ANXA1, B2M, C1QA, and SEC61G expression analysis in glial tumors. Nothern-hybridization of RNA panel with ${ }^{32} \mathrm{P}-\mathrm{marked}$ probe of cDNA ANXA1(A), B2M (B), C1QA(C), SEC61G,(D) and the check sample of cDNA ?-actine(E). Types of tissues and kinds of tumors are marked at blot path, figures in brackets indicate the RNA-sample number. GB - glioblastoma, AA - anaplastic astrocytoma, A - astrocytoma, OA oligoastrocytoma, AO - anaplastic oligodendroglioma, NB - normal human brain. (G) The picture of agarous gel, stained by bromide etidium. (H) The diagram which shows the relative level of gene expression.

libraries of GB altogether and five libraries of NHB altogether revealed 199 gene "tags" with the 5-fold difference in their distribution in these two pools (P\#0.05). Practically all the "tags" correspond to known nucleotide sequences in GenBank, with the exception of two "tags", for which there were no corresponding transcripts found. About $90 \%$ of these known nucleotide sequences are well-characterized mRNA, others are not characterized ESTs (expressing sequence "tags"). Nucleotide sequences, which correspond to "tags" with more than 5-fold surplus in glioblastoma group in comparison with NHB group, can be marked as "overexpressed in tumors", while the ones, which correspond to "tags" with more than 5-fold surplus in NHB group in comparison with glioblastoma group, can be marked as "overexpressed in normal human brain".

"Tags" for hypothetical protein genes, unknown cDNA, mitochondrial genes, as well as the ones which are "unreliable", i.e. internal "tags", located inside mRNA in 

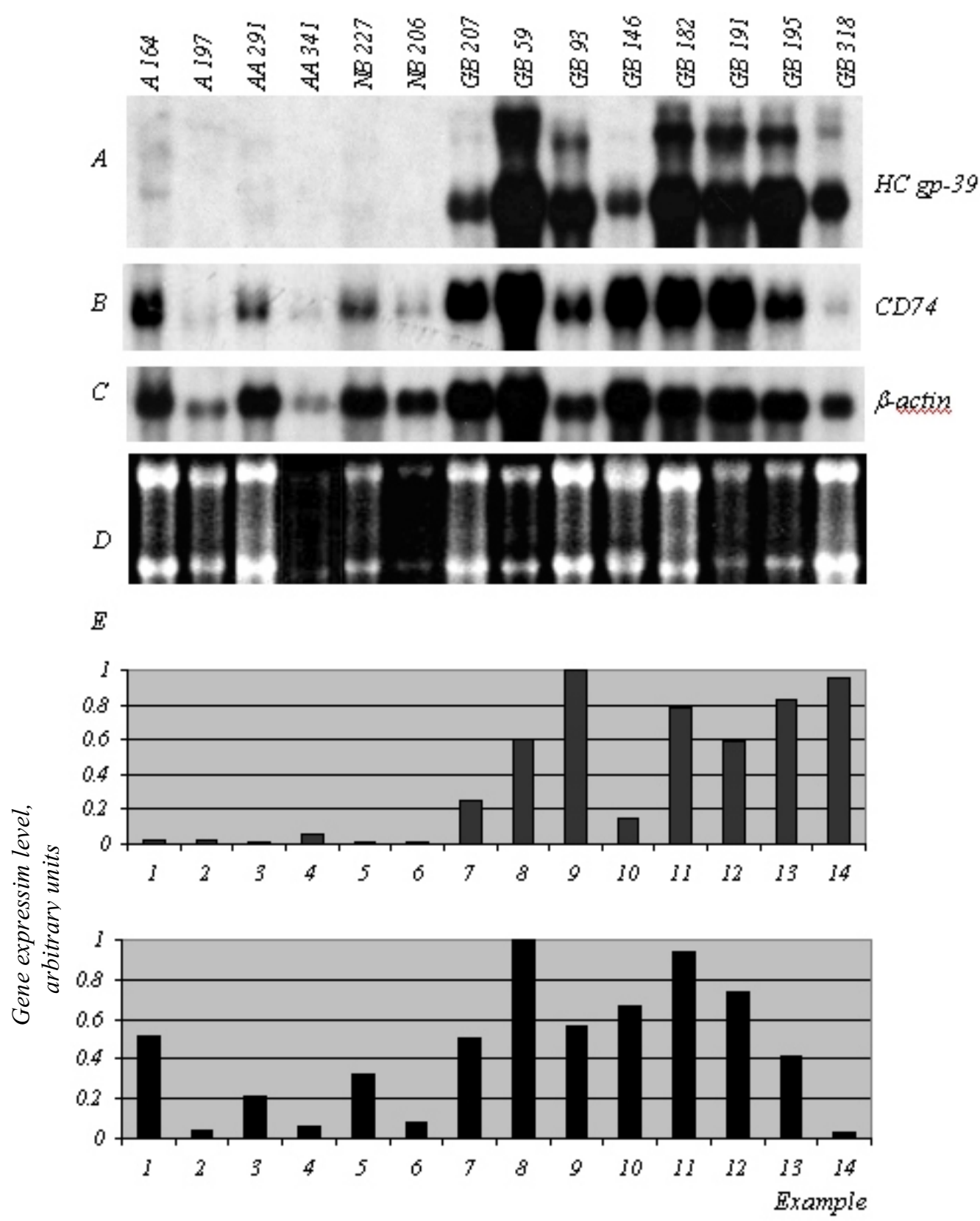

Fig 2. Gene SERPINA3 expression analysis in glial tumors. Nothern-hybridization of RNA panel with ${ }^{32} \mathrm{P}$-marked probe of cDNA SERPINA3(A), and the check sample of cDNA ?-actine (B). Types of tissues and kinds of tumors are marked at blot path, figures in brackets indicate the RNA-sample number. NB - normal human brain, GB - glioblastoma, AA - anaplastic astrocytoma, A - astrocytoma. (C) The picture of agarous gel, stained by bromide etidium. (D) The diagram which shows the relative level of gene expression.

addition to an "true" not extracted "tag", were from the analysis. Thus, 5-fold expression changes in glioblastomas were revealed for 129 genes in all. 44 out of 129 genes correspond to the criterion of being "overexpressed in tumors". They are presented in Table 2. If the coefficient of expression changes is decreased to less than 5 , then the quantity of "overexpressed in tumors" genes will increase, but the genes with greater changes in expression level certainly have greater biological importance. The representatives of this gene group participate in glioma development with great probability $[10,11]$, so we concentrated our at- 

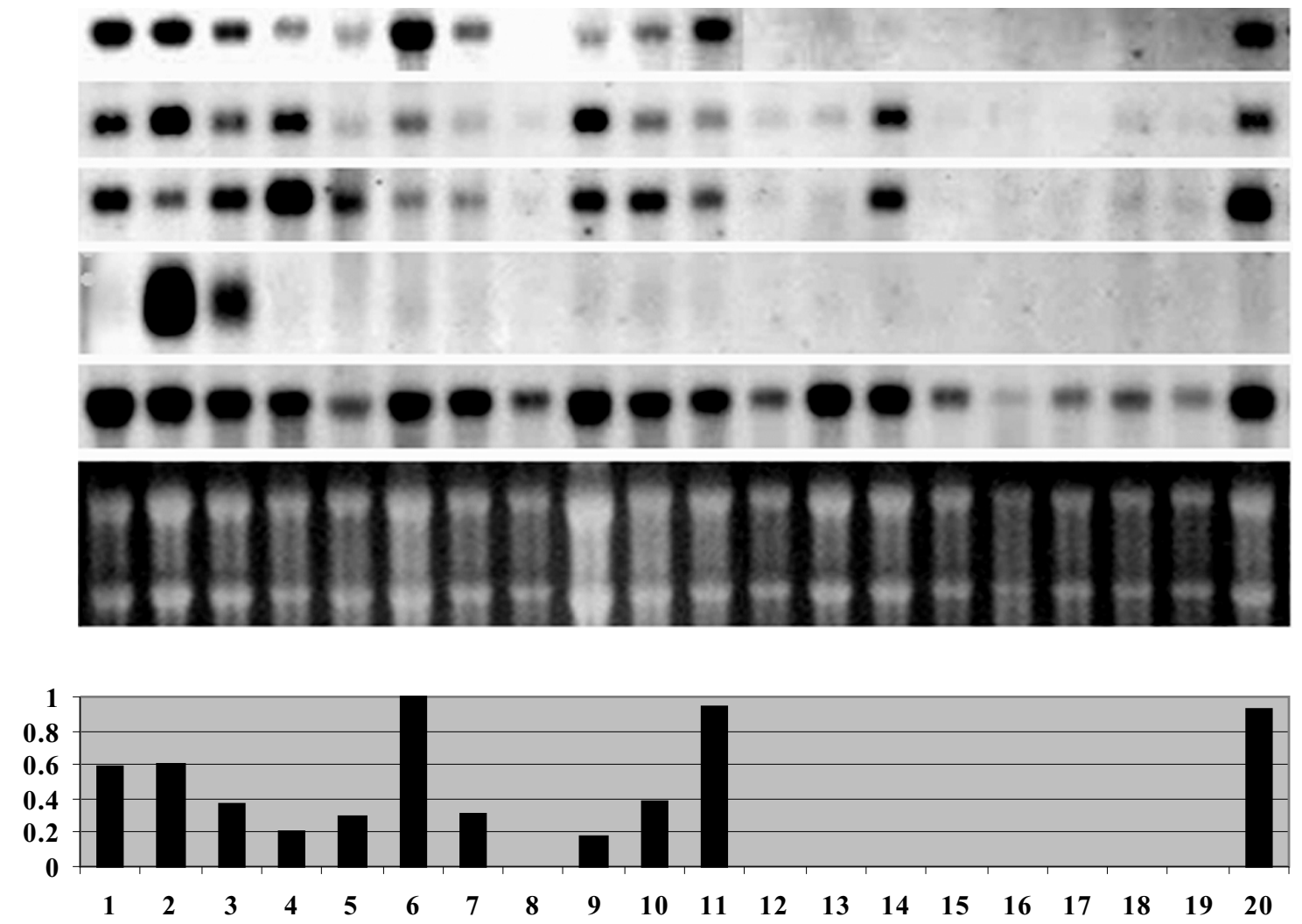

ANXA1

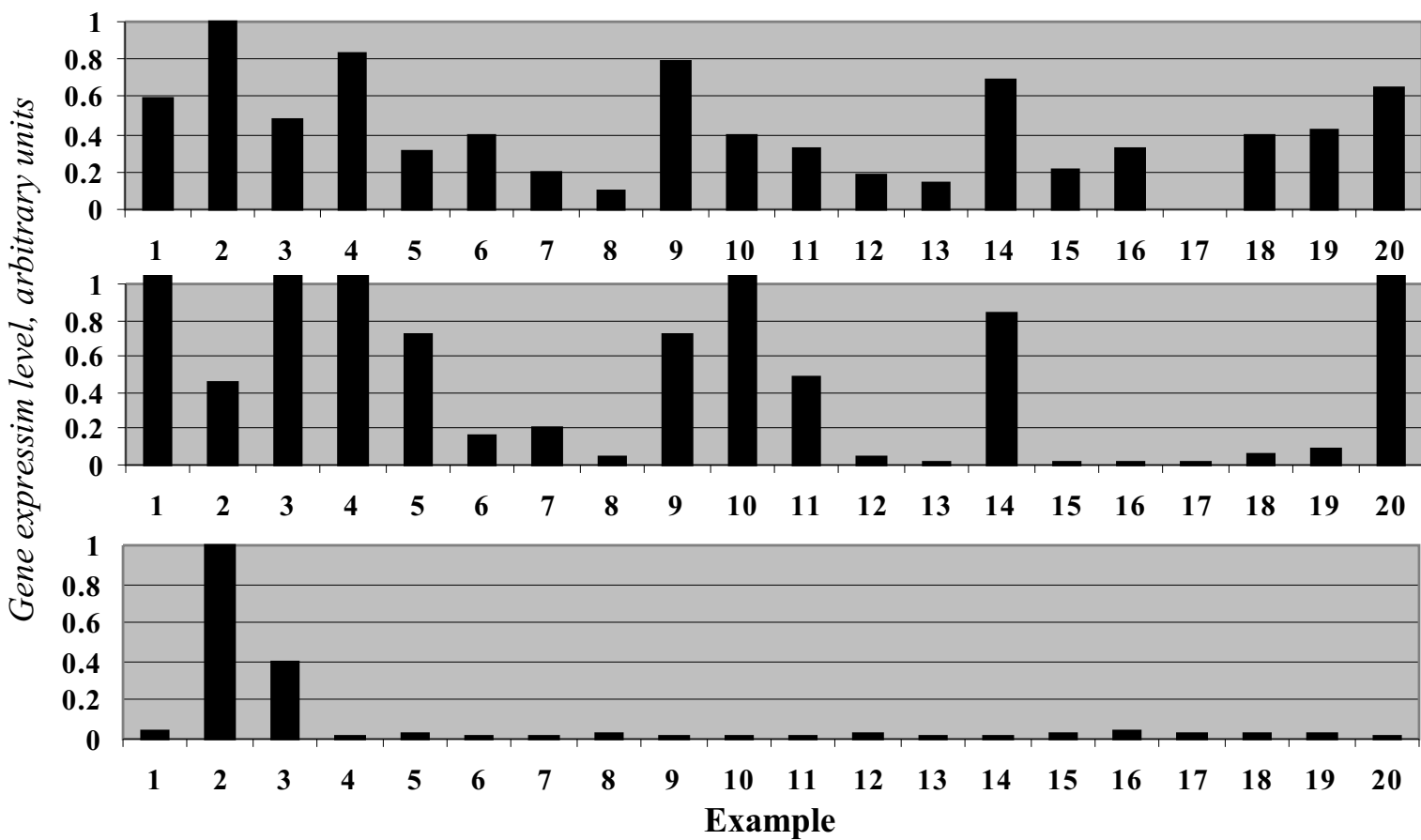

$B 2 M$

Fig 3. Genes HC gp-39 and CD74 expression analysis in glial tumors. Nothern-hybridization of RNA panel with ${ }^{32} \mathrm{P}-$ marked probe of cDNA HC gp-39 (A), CD74 (B) and the check sample of cDNA B-actine (C). Types of tissues and kinds of tumors are marked at blot path, figures in brackets indicate the RNA-sample number. NB - normal human brain, GB - glioblastoma, AA - anaplastic astrocytoma, A - astrocytoma. (D) The picture of agarous gel, stained by bromide etidium. (E) The diagram which shows the relative level of gene expression. 
tention on the research of genes, which are "overexpressed in tumors".

Our research is based on presently existing SAGE-libraries in SAGE Genie database - nine libraries of adult patients' GB, eleven AA libraries, eight libraries of diffue extension of libraries sets can result in some changes in the picture of gene expression. However, the comparison of results, described in this work, to the results, obtained before on five SAGE-libraries of GB and two SAGE-libraries of NHB [9], did not reveal substantial discrepancies in the list of genes, which are differentially expressed.

While comparing eleven SAGE-libraries of AA, taken together, to five SAGE-libraries of NHB at the same analysis conditions (more than 5-fold difference of "tags" distribution and the probability limit $\mathrm{P} \# 0.05$ ) the total quantity of "tags" with 5-fold difference of distribution was revealed to be less (118 "tags"), than while comparing glioblastomas and NHB. No corresponding known transcripts were found for 5 "tags", and others are well-characterized mRNA and not characterized ESTs. After removing the "tags", which correspond to hypothetic protein genes, unknown cDNA, mitochondrial genes, as well as unreliable ones, the total quantity of genes, whose expression changes in AA comparing to NHB, was 66 genes, including 18 genes with the increased expression level. While comparing eight SAGE-libraries of diffusive astrocytomas, taken together, to five SAGE-libraries of NHB 5-fold difference was revealed for 83 "tags", 2 of which did not have corresponding known nucleotide sequences. After the corresponding results processing, 42 genes were revealed to have the expression, changed more than 5-fold in diffusive astrocytomas, and 16 with increased expression.

These results indicate that the quantity of genes, whose expression is stimulated in astrocytic gliomas, increases with the malignant progress of tumors. Some expression changes are revealed at the early stage of astrocytoma formation and are observed on a higher level in more malignant astrocytomas (Table 3). The expression of genes APOC1, B2M, HLA-DRA, IGFBP7, and SPARC (marked in bold in Table 3) increases in diffusive astrocytomas and remain at approximately the same level at the following stages of astrocytoma development. The expression changes are distinctive for some genes only for the most malignant form - glioblastoma (marked in italic in Table 3). It is not quite clear why some genes (located in the bottom of Table 3 ) have a decreased level of expression in anaplastic astrocytomas comparing to diffusive astrocytomas and glioblastomas, where it is much higher than in NHB. Probably, considerably increased expression of these genes is distinctive only for a certain group of tu- mors and is a reflection of the specific way of their development.

To confirm SAGE results and to estimate the levels of gene expression in independent sets of samples of glial tumors and NHB, we selected eight "overexpressed in tumors" transcripts at random and carried out the analysis of their expression with Nothern-hybridization. The selected genes have a sufficient expression level to be determined by this method and though Nothern-hybridization is less sensitive than reverse transcription - polymerase chain reaction (RT-PCR), it has an advantage in determining not only a relative level of gene transcription but also the amount of possible alternative transcripts.

Generally, the pictures of gene expression were reproduced for the analyzed samples of tumors and NHB. Each of eight selected genes had a considerably higher expression level in GB, than in NHB (Pictures 1-3). It is important to emphasize the variations in the level of gene expression in individual tumor samples, which may be explained by heterogeneity of tumor biological properties, which was stated before $[12,13]$. The gene expression varies on a large scale in diffusive and anaplastic astrocytomas for different genes - the levels of gene expression in some tumors are almost as high as in glioblastomas, considerably lower in some tumors, and the gene expression is absent in some, as well as in NHB.

Considering the combinations of expression levels of at least four genes for the tumors of the same malignancy level (Picture 3), one may combine some tumors into separate groups. For example, glioblastomas may be divided into two groups, concerning the expression level of SEC61G gene. Anaplastic astrocytomas AA401 and AA394 have a similar expression profile, AA230 and AA416 also resemble each other. The picture of hybridizational signals for AA199 is similar to glioblastoma GB450, which may testify to a more aggressive character of this anaplastic astrocytoma development. Certainly, the profiles of tumor expression may not be characterized on the basis of expression analysis of four genes, however, the simultaneous analysis of several dozens of genes in a big amount of individual tumors samples must reveal certain molecular variants, which have the same histopathological diagnosis, and combine tumors into separate groups which reflect certain clinical disease peculiarities.

Thus, the malignant progress of astrocytic gliomas is accompanied with expressive changes accumulation. The repetition of these changes in astrocytomas of different levels of anaplasia testifies to the fact that are not accidental, and they probably are a reflection of specific processes in tumor cells. The expression level of the most of "overexpressed in tumor" genes increases gradually at the 
astrocytoma progressing and is the highest in GB. There is a limited quantity of genes, whose expression is activated more than 5-fold at all stages of astrocytoma development, or at least at the last two, the most malignant stages of development. These genes may serve for the recognition of the most malignant tumor variants at the comparison of expressive tumor profiles. The expressive gene changes, distinctive only for GB, may be used for the glioblastoma recognition. Generally, the expression analysis of such genes may be used for the recognition of glial tumors with different malignancy degrees, presumably, for early diagnosis, prognostic purposes and anticancer therapy.

The work was partially financed by the State fund of fundamental researches; project No.F7.282-2001, by the National Academy of Sciences of Ukraine in the framework of the Novelty medical-biological problems and the environment of a human program and by the NATO Collaborative Linkage Grant No.977284.

Дмитренко В. В., Бойко О. И., Шостак Е. А., Симиренко О. Е., Букреева Т. В., Розуменко В. Д., Малышева Т. А., Шамаев М. И., Зозуля Ю. А., Кавсан В. М.

Суперэкспрессия генов на разных стадиях прогрессии астроцитарных глиом

Резюме

Публичная база данных по серийному анализу генной экспрессии (SAGE) была использована для идентификации потенциальны молекулярных маркеров астроцитарных глиом человека. При сравнении девяти SAGE-библиотек глиобластом, одиннадиати SAGE-библиотек анапластических астроцитом, восьми SAGE-библиотек диффузных астроцитом и пяти SAGE-библиотек нормального головного мозга было выявлено 57 генов, уровень экспрессии которых был больше чем в 5 раз выше (P\#0.05) в астроцитарных глиомах по сравнению с нормальным головным мозгом. Кроме изменений экспрессии генов, которые происходят на ранней стадии формирования астроцитом и выявляются также на последующих этапах их развития, некоторые измене ния характерны лишь для высокозлокачественных стадий развития опухолей и отсутствуют в опухолях низкой степени злокачественности. Анализ экспрессии выявленных генов может быть использован для молекулярной классификации глиальных опухолей, диагностики, прогностической оценки опухолей и определения потенциальныхмишеней протиопухолевой терапии.

\section{REFERENCES}

1. Kleihues P., Louis D. N., Scheithauer B. W., Rorke L. B., Reifenberger G., Burger P. C., Cavenee W. K. The WHO classification of tumors of the nervous system // J. Neuropathol. Exp. Neurol. - 2002. - 61. - P.215-225.

2. Watanabe T., Nakamura M., Kros J. M., Burkhard C., Yonekawa Y., Kleihues P., Ohgaki H. Phenotype versus genotype correlation in oligodendrogliomas and low-grade diffuse astrocytomas // Acta Neuropathol. - 2002. - 103. - P.267-275.
3. Okamoto Y., Di Patre P. L., Burkhard C., Horstmann S., Jourde B., Fahey M., Schuler D., Probst-Hensch N. M., Yasargil M. G., Yonekawa Y., Lutolf U. M., Kleihues P., Ohgaki H. Population-based study on incidence, survival rates, and genetic alterations of low-grade diffuse astrocytomas and oligodendrogliomas // Acta Neuropathol. - 2004. -108. - P.49-56.

4. Negm R. S., Verma M., Srivastava S. The promise of biomarkers in cancer screening and detection // Trends Mol. Med. - 2002. - 8. - P.288-293.

5. Huang H., Okamoto Y., Yokoo H., Heppner F. L., Vital A., Fevre-Montange M., Jouvet A., Yonekawa Y., Lazaridis E. $N$., Kleihues P., Ohgaki $H$. Gene expression profiling and subgroup identification of oligodendrogliomas // Oncogene. - 2004. -23. - P.6012-6022.

6. Shai R., Shi T., Kremen T. J., Horvath S., Liau L. M., Cloughesy T. F., Mischel P. S., Nelson S. F. Gene expression profiling identifies molecular subtypes of gliomas // Oncogene. - 2003. -22. -P.4918-4923.

7. Shostak K., Labunskyy V., Dmitrenko V., Malisheva T., Shamayev M., Rozumenko V., Zozulya Y., Zehetner G., Kavsan V. HC gp-39 gene is upregulated in glioblastomas // Cancer Lett. - 2003. - 198. - P.203-210.

8. Dmitrenko V., Shostak K., Boyko O., Khomenko O., Rozumenko V., Malisheva T., Shamayev M., Zozulya Y., Kavsan $V$. Reduction of the transcription level of the mitochondrial genome in human glioblastoma // Cancer Lett. - 2005. -218. - P.99-107.

9. Kavsan V., Shostak K., Dmitrenko V., Chausovskiy T., Zozulya Y., Demotes-Mainard J. Peculiarities of molecular events in human glial tumors revealed by serial analysis of gene expression (SAGE) // Exp. Oncol. - 2004. -26. P.196-204

10. Loging W. T., Lal A., Siu I. M., Loney T. L., Wikstrand C. J., Marra M. A., Prange C., Bigner D. D., Strausberg R. L., Riggins $G$. J. Identifying potential tumor markers and antigens by database mining and rapid expression screening // Genome Res. - 2000. -10. - P.1393-1402.

11. Ljubimova J. Y., Lakhter A. J., Loksh A.,Yong W. H., Riedinger M. S., Miner J. H., Sorokin M. L., Ljubimov A. V., Black $K$. L. Overexpression of $\alpha 4$ chain-containing laminins in human glial tumors identified by gene microarray analysis // Cancer Res. - 2001. -61. P.5601-5610.

12. Cheng Y., Ng H. K., Ding M., Zhang S. F., Pang J. C., Lo K. $W$. Molecular analysis of microdissected de novo glioblastomas and paired astrocytic tumors. J. Neuropathol. Exp. Neurol. -1999. -58. - P.120-128.

13. Zhang L., Zhou W., Velculescu V. E., Kern S. E., Hruban R. $H$., Hamilton S. R., Vogelstein B., Kinzler K. W. Gene expression profiles in normal and cancer cells // Science. 1997. -276. - P.1268-1272.

УДК 577,21:577,214622 Надійшла до рдакції 28.05.04 